\title{
No effect of protein binding ratio of levofloxacin in hemodialysis patients
}

Satoru Mitsuboshi ${ }^{*}$, Hitoshi Yamada $^{1}$, Kazuhiko Nagai $^{1}$ and Kazuyuki Ueno ${ }^{2}$

\begin{abstract}
Background: Few studies have examined the protein binding ratio of levofloxacin (LVFX) in patients undergoing hemodialysis (HD).

Methods: We evaluated the serum concentration and protein binding ratio of LVFX in HD patients. Subjects were 13 patients (7 non-HD and 6 HD patients) undergoing LVFX therapy for pneumonia, urinary tract infection, osteomyelitis, and unidentified infections from June 2012 to December 2013. To clarify the relationship between protein concentration and the protein binding ratio of LVFX in vitro and in vivo, the effect of human albumin and globulin on the binding ratio was investigated.

Results: The protein binding ratio of LVFX was 31.2 and $29.3 \%$ in non-HD and HD patients, respectively. A statistically significant correlation was observed between the serum albumin level and protein binding ratio in vivo. LVFX was bound to not only albumin but also globulin; further, in vitro, the protein binding ratio of LVFX increased with an increase in the albumin or globulin concentration. However, the protein binding ratio did not increase with increased serum globulin concentrations in the presence of $3.5 \mathrm{~g} / \mathrm{dL}$ albumin.

Conclusions: The protein binding ratio of LVFX has little clinical relevance, and it is not necessary to monitor it for LVFX therapy in HD patients.
\end{abstract}

Keywords: Levofloxacin, Protein binding, Hemodialysis

\section{Background}

Levofloxacin (LVFX) belongs to the fluoroquinolone class of antimicrobial agents, with broad-spectrum activity against Gram-positive and Gram-negative bacteria, including Pseudomonas aeruginosa [1]. Because of its clinical and bacteriological efficacy, LVFX is an important antimicrobial drug for treating serious infections [2].

LVFX is excreted primarily unchanged by the kidneys $(79.6 \%)$ [1]. Its elimination half-life ranges from 4.3 to $8.9 \mathrm{~h}$ in individuals with normal renal function [1] and from 18.4 to $43.5 \mathrm{~h}$ in hemodialysis (HD) patients [3]. The serum protein binding ratio of LVFX is approximately $24-38 \%$, and it is mainly bound to serum albumin in humans [1]. The 24-h area under the curve/ minimum inhibitory concentration $\left(\mathrm{AUC}_{24} / \mathrm{MIC}\right)$ ratio correlates with the efficacy of fluoroquinolones [4]. An $\mathrm{AUC}_{24} / \mathrm{MIC}$ ratio of 125 is correlated with optimal

\footnotetext{
* Correspondence: ccrtyo34057@gmail.com

'Department of Pharmacy, Kaetsu Hospital, 1459-1 Higashikanazawa,

Akiha-ku, Niigata-shi, Niigata 956-0814, Japan

Full list of author information is available at the end of the article
}

clinical and microbiological outcomes in seriously ill patients infected with Gram-negative bacteria [5], while a free-drug $\mathrm{AUC}_{24} / \mathrm{MIC}$ ratio $>33.7$ has been associated with $100 \%$ microbiological response in respiratory tract infections caused by Streptococcus pneumoniae [6]. Protein binding of fluoroquinolones has been considered to be of uncertain clinical relevance. It appears more desirable to have high levels of freely available drug so that it is clinically active than to have a large proportion of bound and potentially inactive drug [7]. In vitro examinations have demonstrated that protein binding leads to a significant reduction in the antimicrobial activity of moxifloxacin and trovafloxacin [8,9]. Scaglione et al. [10] reported that the unbound fraction (67-88 \%) was concentration dependent for LVFX and ciprofloxacin $(0.5-80 \mathrm{mg} / \mathrm{L})$ in a murine pneumonia model and that protein binding may affect the pharmacodynamics of fluoroquinolones.

The protein binding ratio of various drugs is associated with the presence of uremic toxins caused by renal 
failure [11] as well as hypoalbuminemia due to hepatic failure, advanced age, inflammatory diseases, and cancers [7]. We hypothesized that in HD patients, the protein binding ratio of LVFX would fluctuate widely, potentially affecting antimicrobial activity. However, little information is available regarding the protein binding ratio of LVFX in HD patients. Therefore, this study aimed to evaluate the serum concentration and protein binding ratio of LVFX in HD patients.

\section{Methods}

\section{Materials}

LVFX and pazufloxacin (PZFX) were provided by Daiichi Sankyo Co., Ltd. (Tokyo, Japan) and Taisho-Toyama Pharmaceuticals Co., Ltd. (Tokyo, Japan), respectively. Oasis HLB $1-\mathrm{cm}^{3}$ (30-mg) extraction cartridges were obtained commercially from Waters Corporation (Milford, MA). Human albumin and globulin were purchased from Wako Pure Chemical Industries (Osaka, Japan). All other chemicals were of analytical grade and commercially available.

\section{Subjects}

Clinical laboratory data were collected from 13 patients, including 7 non-HD patients and $6 \mathrm{HD}$ patients, who were undergoing LVFX therapy for pneumonia, urinary tract infection, osteomyelitis, and unidentified infections from June 2012 to December 2013. Non-HD patients received LVFX $500 \mathrm{mg}$ once daily orally, and HD patients received LVFX $500 \mathrm{mg}$ initially, followed by $250 \mathrm{mg}$ after each HD session orally. All subjects were administered LVFX therapy for 4-48 days. HD patients underwent thrice-weekly HD in the LVFX treatment period. Written informed consent was obtained from all subjects before enrollment in this study. This study and its protocol were approved by the Ethics Committee of Kaetsu Hospital.

\section{Blood sampling}

To determine the serum concentration of LVFX and to obtain other laboratory data, blood samples were obtained just before HD and on non-HD days in HD patients and just before LVFX administration and $12 \mathrm{~h}$ after administration in non-HD patients. Blood sampling times were different in order to obtain appropriate clinical blood samples to evaluate infectious diseases. Blood samples were obtained 2-18 days after the administration of LVFX was initiated. Both total and free fraction concentrations of LVFX were measured in the $13 \mathrm{pa}-$ tients to determine the correlations between serum albumin, serum globulin, serum concentration of LVFX, and protein binding ratio of LVFX. To clarify the relationship between protein concentration and the protein binding ratio of LVFX in vitro and in vivo, the effect of human albumin and globulin on the protein binding ratio of LVFX in phosphate buffer ( $\mathrm{pH}$ 7.4) was investigated.

\section{Preparation of sample solutions}

To determine the relationship between the serum concentration $(1,2,4,8,10$, and $20 \mathrm{mg} / \mathrm{L}$ as the general serum concentration and 50 and $100 \mathrm{mg} / \mathrm{L}$ as the high serum concentration) and the protein binding ratio of LVFX in vitro, the effect of the protein binding ratio was investigated using $0.025 \mathrm{M}$ phosphate buffer solution ( $\mathrm{pH}$ 7.5). To determine the relationship between the protein concentration and the protein binding ratio of LVFX in vitro, the effect of human albumin and globulin on the binding ratio was investigated using $0.025 \mathrm{M}$ phosphate buffer solution ( $\mathrm{pH} 7.5)$. After the samples were incubated for $30 \mathrm{~min}$ at $37^{\circ} \mathrm{C}$, the free fraction of the samples was obtained by ultrafiltration (molecular weight cutoff, 10,000 Da).

\section{Assay}

Serum LVFX concentrations were determined by HPLC using PZFX as the internal standard (IS). Briefly, sample processing was performed using a solid phase extraction cartridge. The cartridges were conditioned with methanol and water. After the sample $(100 \mu \mathrm{L}$ serum sample + $100 \mu \mathrm{L}$ IS $+900 \mu \mathrm{L} 0.025 \mathrm{M}$ phosphate buffer solution; $\mathrm{pH}$ 7.5) was loaded, the cartridge was washed with $1 \mathrm{~mL}$ of $5 \%$ methanol in water. The sample was eluted with $1 \mathrm{~mL}$ of mobile phase, and $50 \mu \mathrm{L}$ was injected onto the HPLC column for analysis. The HPLC system consisted of a reverse-phase column (Shim-pack, CLC-CN, Shimadzu Corp., Kyoto, Japan), and the fluorescence of the mobile phase was monitored (excitation wavelength, $278 \mathrm{~nm}$; emission wavelength, $445 \mathrm{~nm}$ ). The mobile phase consisted of a mixture ( $\mathrm{pH}$ 3.0) of phosphate buffer, acetonitrile, and triethylamine (171:29:1 by volume), and the flow rate was $1.0 \mathrm{~mL} / \mathrm{min}$. The retention times of the IS and LVFX were 6.0 and $6.8 \mathrm{~min}$, respectively. The lower limit of quantification of this system was $0.05 \mu \mathrm{g} / \mathrm{mL}$ in $0.1 \mathrm{~mL}$ of serum. Inter- and intra-day variations were $<5.0 \%$. The free fractions of the serum and spiked samples were obtained by ultrafiltration using a disposable ultrafilter (Kurabo Industries, Ltd., Osaka, Japan). The protein binding ratio of LVFX was calculated from the total and free concentration of LVFX.

\section{Statistical analysis}

Data are expressed as mean \pm standard deviation. Statistical analysis was performed using the Student's $t$ test or Pearson's correlation coefficient test, and significance was set at $p<0.05$. JMP 9 Software (SAS Institute Inc., Cary, NC) was used for all statistical analyses. 
Table 1 Patient profiles and serum concentration and protein binding ratio of levofloxacin

\begin{tabular}{llll}
\hline & $\begin{array}{l}\text { Non-HD patients } \\
(n=7)\end{array}$ & $\begin{array}{l}\text { HD patients } \\
(n=6)\end{array}$ & $p^{\text {a }}$ \\
\hline Age (years) & $80.9 \pm 12.1$ & $75.3 \pm 15.3$ & 0.48 \\
Sex (female/male) & $6 / 1$ & $0 / 6$ & - \\
Body weight $(\mathrm{kg})$ & $44.5 \pm 12.2$ & - & - \\
Dry weight $(\mathrm{kg})$ & - & $60.6 \pm 18.4$ & 0.09 \\
Serum creatinine $(\mathrm{mg} / \mathrm{dL})$ & $0.7 \pm 0.3$ & $8.9 \pm 3.9$ & $<0.05$ \\
Total protein $(\mathrm{g} / \mathrm{dL})$ & $6.3 \pm 0.4$ & $6.2 \pm 0.7$ & 0.63 \\
Albumin $(\mathrm{g} / \mathrm{dL})$ & $3.1 \pm 0.4$ & $3.4 \pm 0.5$ & 0.35 \\
Serum concentration of & $4.5 \pm 2.6$ & $5.2 \pm 2.3$ & 0.62 \\
LVFX (mg/L) & & & \\
Protein binding ratio of LVFX (\%) & $31.2 \pm 5.3$ & $29.3 \pm 6.4$ & 0.55 \\
\hline
\end{tabular}

Values represent means \pm standard deviation

$H D$ hemodialysis, LVFX levofloxacin

${ }^{a}$ The statistical difference was determined by Student's $t$ test for non-HD patients vs. HD patients. Statistical analysis of weight involving total body weight in non-HD patients vs. dry weight in HD patients

\section{Results}

Patient profiles, serum concentrations, and protein binding ratios of LVFX are shown in Table 1 . For HD patients, demographic profiles, HD backgrounds, LVFX concentrations, and protein binding ratios are shown in Table 2. Serum globulin was not measured in one patient. For non-HD patients, the demographic profiles, backgrounds, LVFX concentrations, and protein binding ratios are shown in Table 3. Serum globulin was not measured in all patients. In HD patients, serum LVFX concentrations and protein binding ratio were $4.3 \pm$ $2.2 \mathrm{mg} / \mathrm{dL}$ and $27.3 \pm 6.6 \%$ just before $\operatorname{HD}(n=4)$ and $7.1 \pm 0.8 \mathrm{mg} / \mathrm{dL}$ and $33.2 \pm 5.1 \%$ on non-HD days $(n=2)$, respectively. In non-HD patients, serum LVFX concentrations and protein binding ratio were $3.7 \pm$ $2.7 \mathrm{mg} / \mathrm{dL}$ and $33.4 \pm 4.7 \%$ just before the administration of LVFX $(n=5)$ and $6.6 \pm 1.2 \mathrm{mg} / \mathrm{dL}$ and $25.9 \pm 1.6 \%$ on $12 \mathrm{~h}$ after the administration of LVFX $(n=2)$, respectively.

The relationship between the serum albumin concentration and protein binding ratio of LVFX in HD $(p=0.16, r=0.66)$ and non-HD patients $(p=0.05, r=$ $0.75)$ is shown in Fig. 1, wherein a statistically significant $(p=0.03)$ correlation $(r=0.60)$ was observed in all the patients. Among the oral medications taken by the patients, those known to have interactions with LVFX administered concurrently in HD patients were as follows: iron agents $50 \mathrm{mg}$ taken by patient no. 3 , lanthanum carbonate hydrate $750 \mathrm{mg}$ and sevelamer hydrochloride $1500 \mathrm{mg}$ taken by patient no. 4, and calcium carbonate $500 \mathrm{mg}$ taken by patient no. 6 . The oral medication known to have interactions with LVFX administered concurrently in non-HD patients was magnesium oxide $250 \mathrm{mg}$ taken by patient no. 3 .

In contrast, the relationship between the serum concentration and protein binding ratio of LVFX in patients showed no statistically significant $(p=0.96)$ correlation $(r=0.02)$. In vitro, the relationship between the serum concentration and protein binding ratio of LVFX in human serum, as observed in Fig. 2, showed no statistically significant $(p=0.91)$ correlation $(r=0.03)$. The relationship between the serum albumin concentration and protein binding ratio of LVFX in phosphate buffer $(\mathrm{pH}$ 7.4), that between the serum globulin concentration and protein binding ratio of LVFX in phosphate buffer $(\mathrm{pH}$ 7.4 ), and that between the serum globulin concentration and protein binding ratio of LVFX in phosphate buffer (pH 7.4) containing $3.5 \mathrm{~g} / \mathrm{dL}$ albumin are shown Figs. 3, 4 , and 5 , respectively. It was observed that the protein

Table 2 Hemodialysis patients' demographic profiles, hemodialysis backgrounds, levofloxacin concentrations, and protein binding ratios

\begin{tabular}{|c|c|c|c|c|c|c|c|c|c|c|c|c|c|}
\hline Patient no. & $\begin{array}{l}\text { Age } \\
\text { (years) }\end{array}$ & Sex & DW (kg) & $\operatorname{SAr}\left(\mathrm{m}^{2}\right)$ & DM & $\mathrm{BFR}(\mathrm{mL} / \mathrm{min})$ & $\pi(h)$ & BST (h) & $\mathrm{SP}(\mathrm{g} / \mathrm{dL})$ & $\mathrm{SA}(\mathrm{g} / \mathrm{dL})$ & $\mathrm{SG}(\mathrm{g} / \mathrm{dL})$ & LVFX (mg/L) & PBR (\%) \\
\hline 1 & 52 & Male & 96.0 & 2.2 & PS & 250 & 5 & $\begin{array}{l}\text { Just before } \\
\text { HD }\end{array}$ & 6.9 & 3.9 & 3.0 & 4.0 & 30.9 \\
\hline 2 & 88 & Male & 48.7 & 0.9 & CTA & 160 & 3 & $\begin{array}{l}\text { Just before } \\
\text { HD }\end{array}$ & 6.0 & 3.6 & - & 3.9 & 34.5 \\
\hline 3 & 82 & Male & 51.5 & 1.1 & PES & 160 & 4 & Non-HD days & 5.0 & 2.8 & 2.2 & 7.6 & 29.6 \\
\hline 4 & 62 & Male & 64.0 & 1.9 & PES & 220 & 4 & $\begin{array}{l}\text { Just before } \\
\text { HD }\end{array}$ & 6.4 & 3.2 & 3.1 & 1.9 & 20.0 \\
\hline 5 & 91 & Male & 47.5 & 1.1 & PES & 180 & 4 & $\begin{array}{l}\text { Just before } \\
\text { HD }\end{array}$ & 6.5 & 2.7 & 3.6 & 7.3 & 23.7 \\
\hline 6 & 77 & Male & 55.8 & 1.9 & PES & 200 & 4 & Non-HD days & 6.4 & 3.9 & 2.5 & 6.5 & 36.8 \\
\hline Average & 75.3 & & 60.6 & 1.5 & & 195.0 & 4.0 & & 6.2 & 3.4 & 2.9 & 5.2 & 29.3 \\
\hline SD & 15.3 & & 18.4 & 0.5 & & 35.6 & 0.6 & & 0.7 & 0.5 & 0.5 & 2.3 & 6.4 \\
\hline
\end{tabular}

$S D$ standard deviation, $D W$ dry weight, $S A r$ surface area, $D M$ dialyzer membrane, $B F R$ blood flow rate, $T$ treatment time, $B S T$ blood sampling time after administration of levofloxacin, SP serum protein, SA serum albumin, SG serum globulin, LVFX serum levofloxacin concentration, PBR protein binding ratio, $H D$ hemodialysis, PS polysulfone, CTA cellulose triacetate, PES polyether sulfone 
Table 3 Non-hemodialysis patients' demographic profiles, backgrounds, levofloxacin concentrations, and protein binding ratios

\begin{tabular}{|c|c|c|c|c|c|c|c|c|c|}
\hline Patient no. & Age (years) & Sex & BW (kg) & $\mathrm{Scr}(\mathrm{mg} / \mathrm{dL})$ & BST (h) & $\mathrm{SP}(\mathrm{g} / \mathrm{dL})$ & $S A(g / d L)$ & LVFX (mg/L) & PBR (\%) \\
\hline 1 & 59 & Female & 63.8 & 0.9 & Just before administration & 6.6 & 3.7 & 4.8 & 38.8 \\
\hline 2 & 95 & Female & 35.0 & 0.7 & Just before administration & 6.2 & 2.9 & 7.7 & 31.6 \\
\hline 3 & 88 & Female & 33.3 & 0.4 & Just before administration & 6.3 & 3.4 & 3.1 & 37.5 \\
\hline 4 & 87 & Female & 32.8 & 0.4 & Just before administration & 6.8 & 3.0 & 1.2 & 27.7 \\
\hline 5 & 72 & Male & 43.9 & 1.0 & $12 \mathrm{~h}$ & 5.9 & 2.6 & 5.7 & 24.8 \\
\hline 6 & 86 & Female & 57.2 & 1.0 & $12 \mathrm{~h}$ & 5.9 & 3.3 & 7.4 & 27.0 \\
\hline 7 & 79 & Female & 45.7 & 0.5 & Just before administration & 6.7 & 2.8 & 1.6 & 31.2 \\
\hline Average & 80.9 & - & 44.5 & 0.7 & - & 6.3 & 3.1 & 4.5 & 31.2 \\
\hline SD & 12.1 & - & 12.2 & 0.3 & - & 0.4 & 0.4 & 2.6 & 5.3 \\
\hline
\end{tabular}

$S D$ standard deviation, $B W$ body weight, $S c r$ serum creatinine, $B S T$ blood sampling time after administration of levofloxacin, $S P$ serum protein, $S A$ serum albumin, LVFX serum levofloxacin concentration, $P B R$ protein binding ratio

binding ratio increased with an increase in the serum albumin $(r=0.82, p=0.09)$ and globulin $(r=0.93, p=0.02)$ concentrations. However, the protein binding ratio did not increase with an increase in the serum globulin concentration when the buffer also contained $3.5 \mathrm{~g} / \mathrm{dL}$ albu$\min (r=0.40, p=0.43)$.

\section{Discussion}

The protein binding ratios of fluoroquinolones are known to affect antimicrobial activity in vitro [8-10]. Protein binding is associated with the presence of uremic toxins [11], among other factors. Thus, in HD patients, it is possible that the protein binding ratio of LVFX may fluctuate greatly, thereby affecting antimicrobial activity. However, to date, little data is available regarding the protein binding ratio of LVFX in HD patients.

Our findings showed that the protein binding ratios of LVFX were 31.2 and $29.3 \%$ in non-HD and HD patients, respectively, and that the ratio did not fluctuate significantly in HD patients. A possible reason why this ratio did not fluctuate in HD patients is that LVFX does not

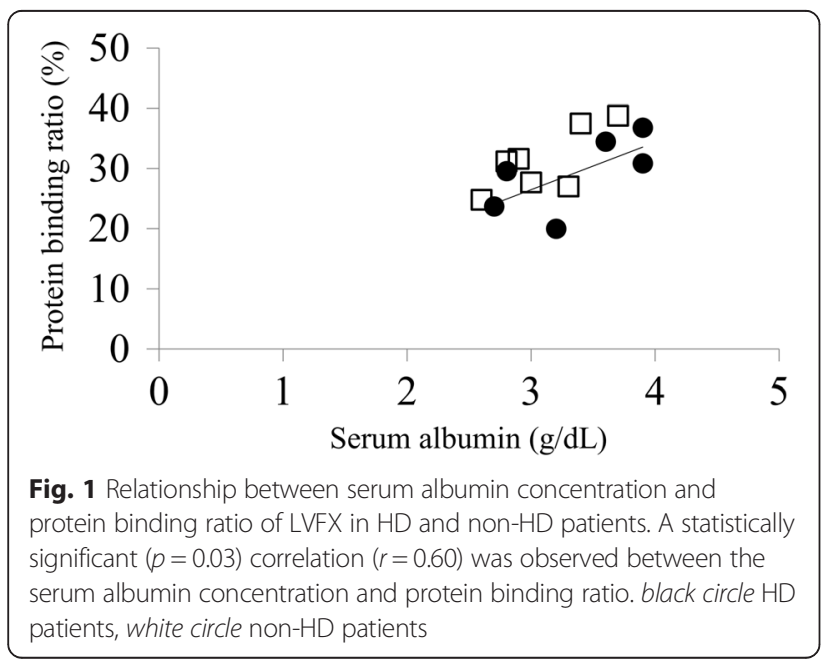

show very high binding to serum proteins (approximately 24-38 \%) [1] compared with other drugs [11] (e.g., fosphenytoin 93-98 \%). Therefore, the protein binding ratio of LVFX was found to be similar in HD and non-HD patients, in agreement with a previous study [1]. Thus, the protein binding ratio of LVFX is not associated with the presence of uremic toxins, and the protein binding ratio holds little clinical relevance for LVFX therapy in HD patients.

As shown in Fig. 1, a statistically significant correlation was observed between the serum albumin concentration and the protein binding ratio in $\mathrm{HD}$ and non-HD patients. However, such a correlation was not observed between the serum LVFX concentration and protein binding ratio in vitro (Fig. 2) or in vivo. Therefore, we considered that the protein binding ratio of LVFX was primarily affected by the serum albumin concentration, as reported by Bergogne-Bérézin [7]. Four patients received medications with known interactions with LVFX. Fluoroquinolones are known to interact with drugs containing calcium [12], iron [13], and lanthanum [14] via chelation interactions; they are also known to interact with sevelamer [15], manifesting as decreased oral bioavailability. It is unclear whether these drugs affected

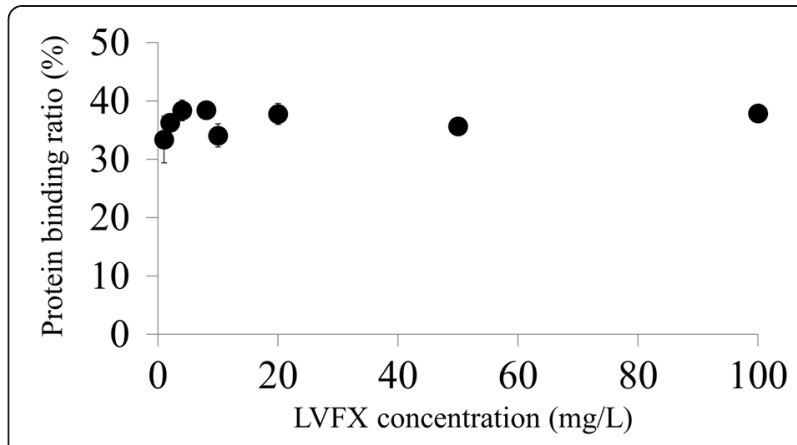

Fig. 2 Relationship between serum concentration and protein binding ratio of LVFX in human serum (in vitro). Mean \pm standard deviation of three experiments 


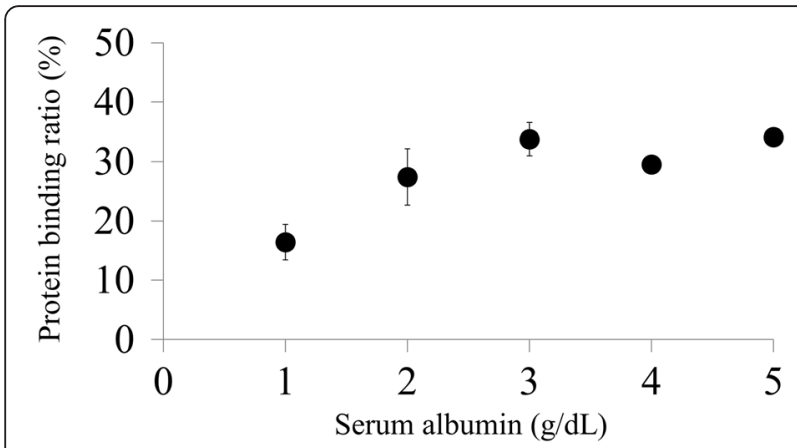

Fig. 3 Relationship between serum albumin concentration and protein binding ratio of LVFX in phosphate buffer ( $\mathrm{pH}$ 7.4). Mean \pm standard deviation of three experiments

LVFX concentrations in this study. However, we considered that the protein binding ratio of LVFX had a minimal effect on the patients who received such medications because the protein binding ratio was not associated with serum LVFX concentrations.

As shown in Figs. 3, 4, and 5, LVFX was bound to not only albumin but also globulin. Moreover, the protein binding ratio of LVFX increased with increased concentrations of albumin as well as globulin. No studies have reported that LVFX and other fluoroquinolones show protein binding to serum globulin. However, the protein binding ratio did not increase with increased serum globulin concentrations in the presence of $3.5 \mathrm{~g} / \mathrm{dL}$ albumin. We therefore considered that the globulin binding ratio had a minimal effect on the protein binding ratio since the globulin binding ratio is lower than the albumin binding ratio. These results suggested that the protein binding ratio of LVFX was minimally affected by serum globulin concentrations. However, if patients had severe hypoalbuminemia, the protein binding ratio may be affected by serum globulin levels.

Our study has certain limitations. These include the small sample size, few female patients among the HD patients, and body weight that tended to be higher in

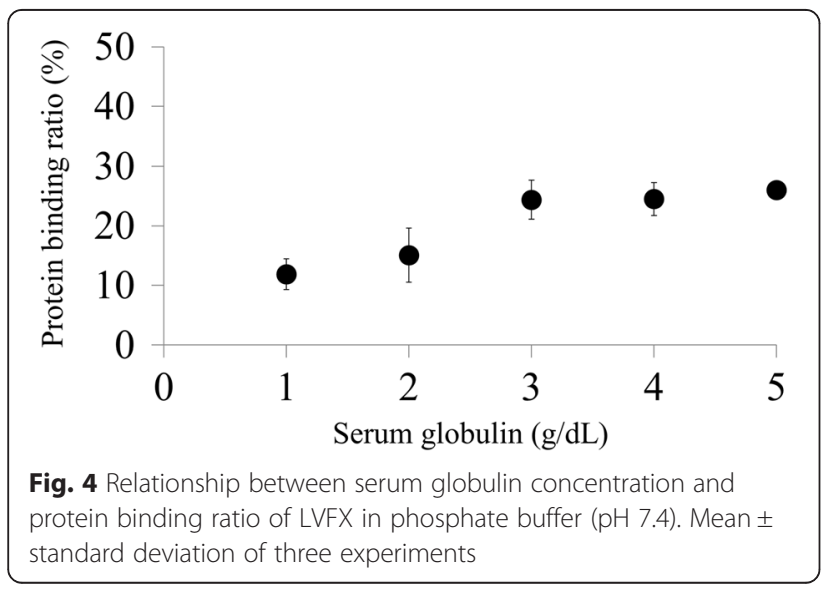

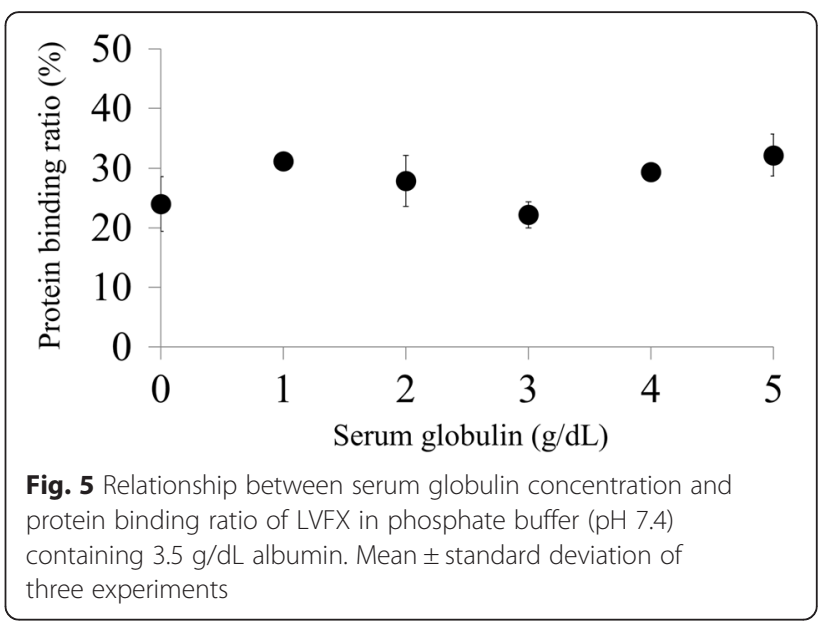

the HD patient group compared with the non-HD patient group. In addition, the protein binding ratio is reportedly affected by the $\mathrm{pH}$ [7], but we did not measure the serum $\mathrm{pH}$. Moreover, we did not evaluate the effect of hemodialysis on the protein binding ratio and severe hypoalbuminemia.

\section{Conclusions}

Overall, our results indicated no differences in the protein binding ratio of LVFX between non-HD and HD patients. Moreover, LVFX showed binding to both albumin and globulin; however, the protein binding ratio of LVFX was mainly affected by serum albumin concentrations. Thus, the protein binding ratio of LVFX appears to have little clinical relevance, and we consider that it is not necessary to monitor this parameter for LVFX therapy in HD patients.

Competing interests

The authors declare that they have no competing interests.

\section{Authors' contributions}

SM planned the study, carried out the HPLC assay, extracted the data, analyzed the data, and prepared the article. HY and KN assessed the studies and assisted in the article preparation. KU planned the study, assessed the studies, and assisted in the article preparation. All authors read and approved the final manuscript.

Acknowledgements

The authors thank the staff and participants in this study.

\section{Author details}

'Department of Pharmacy, Kaetsu Hospital, 1459-1 Higashikanazawa, Akiha-ku, Niigata-shi, Niigata 956-0814, Japan. ${ }^{2}$ Department of Pharmaceutical Sciences, Niigata University of Pharmacy and Applied Life Sciences, 265-1 Higashijima, Akiha-ku, Niigata 956-8603, Japan.

Received: 21 January 2016 Accepted: 8 April 2016

Published online: 11 July 2016

References

1. Fish DN, Chow AT. The clinical pharmacokinetics of levofloxacin. Clin Pharmacokinet. 1997;32:101-19. 
2. Benko R, Matuz M, Doro P, et al. Pharmacokinetics and pharmacodynamics of levofloxacin in critically ill patients with ventilator-associated pneumonia. Int J Antimicrob Agents. 2007;30:162-8.

3. Tsuruoka S, Yokota N, Hayasaka T, et al. Pharmacokinetics of multiple-dose levofloxacin in hemodialysis patients. Am J Kidney Dis. 2011;58:498-9.

4. Craig WA. Pharmacokinetic/pharmacodynamic parameters: rationale for antibacterial dosing of mice and men. Clin Infect Dis. 1998;26:1-12.

5. Forrest A, Nix DE, Ballow $\mathrm{CH}$, et al. Pharmacodynamics of intravenous ciprofloxacin in seriously ill patients. Antimicrob Agents Chemother. 1993;37: 1073-81.

6. Ambrose PG, Grasela DM, Grasela TH, et al. Pharmacodynamics of fluoroquinolones against Streptococcus pneumoniae in patients with community-acquired respiratory tract infections. Antimicrob Agents Chemother. 2001;45:2793-7.

7. Bergogne-Bérézin E. Clinical role of protein binding of quinolones. Clin Pharmacokinet. 2002;41:741-50.

8. Zeitlinger $M$, Sauermann R, Fille $M$, et al. Plasma protein binding of fluoroquinolones affects antimicrobial activity. J Antimicrob Chemother. 2008;61:561-7.

9. Zeitlinger M, Sauermann R, Traunmüller $F$, et al. Impact of plasma protein binding on antimicrobial activity using time-killing curves. J Antimicrob Chemother. 2004:54:876-80.

10. Scaglione F, Mouton JW, Mattina R, et al. Pharmacodynamics of levofloxacin and ciprofloxacin in a murine pneumonia model: peak concentration/MIC versus area under the curve/MIC ratios. Antimicrob Agents Chemother. 2003:47:2749-55

11. Dasgupta A, Havlik D. Elevated free fosphenytoin concentrations in uremic sera: uremic toxins hippuric acid and indoxyl sulfate do not account for the impaired protein binding of fosphenytoin. Ther Drug Monit. 1998;20:658-62.

12. Neuhofel $A L$, Wilton JH, Victory JM, et al. Lack of bioequivalence of ciprofloxacin when administered with calcium-fortified orange juice: a new twist on an old interaction. J Clin Pharmacol. 2002;42:461-6.

13. Lode $\mathrm{H}$. Evidence of different profiles of side effects and drug-drug interactions among the quinolones-the pharmacokinetic standpoint. Chemotherapy. 2001:47:24-31.

14. How PP, Fischer JH, Arruda JA, et al. Effects of lanthanum carbonate on the absorption and oral bioavailability of ciprofloxacin. Clin J Am Soc Nephrol. 2007;2:1235-40

15. Kays MB, Overholser BR, Mueller BA, et al. Effects of sevelamer hydrochloride and calcium acetate on the oral bioavailability of ciprofloxacin. Am J Kidney Dis. 2003:42:1253-9.

\section{Submit your next manuscript to BioMed Central and we will help you at every step:}

- We accept pre-submission inquiries

- Our selector tool helps you to find the most relevant journal

- We provide round the clock customer support

- Convenient online submission

- Thorough peer review

- Inclusion in PubMed and all major indexing services

- Maximum visibility for your research

Submit your manuscript at www.biomedcentral.com/submit

) Biomed Central 